\title{
Inhibition of glucose stimulated insulin secretion by neuropeptide $Y$ is mediated via the $Y 1$ receptor and inhibition of adenylyl cyclase in RIN 5AH rat insulinoma cells
}

\author{
D.G. Morgan ${ }^{1}$, R. N. Kulkarni ${ }^{2}$, J.D. Hurley ${ }^{3}$, Z. L.Wang ${ }^{1}$, R.M. Wang ${ }^{1}$, M. A. Ghatei ${ }^{1}$, A. E. Karlsen ${ }^{4}$, S. R. Bloom ${ }^{1}$, \\ D.M. Smith ${ }^{1}$ \\ ${ }^{1}$ ICSM Endocrine Unit at the Hammersmith Hospital, Imperial College School of Medicine, London, UK \\ ${ }^{2}$ Department of Cellular and Molecular Physiology, Joslin Diabetes Center, Harvard Medical School, Boston, Massachusetts, \\ USA \\ ${ }^{3}$ Department of Experimental Medicine, Harvard Institute of Medicine, Boston Massachusetts, USA \\ ${ }^{4}$ Steno Diabetes Center, Gentofte, Denmark
}

\begin{abstract}
Summary Neuropeptide Y (NPY) has been shown to inhibit insulin secretion from the islets of Langerhans. We show that insulin secretion in the insulinoma cell line RIN 5AH is inhibited by NPY. ${ }^{125}$ I-Peptide YY (PYY) saturation and competition-binding studies using NPY fragments and analogues on membranes prepared from this cell line show the presence of a single class of NPY receptor with a Y1 receptor subtype-like profile. Inhibition of insulin secretion in this cell line by NPY fragments and analogues also shows a Y1 receptor-like profile. Both receptor binding and inhibition of insulin secretion showed the same orders of potency with NPY $>\left[\mathrm{Pro}^{34}\right]-$ NPY > NPY 3-36 > > NPY 13-36. The Y1 receptor antagonist, BIBP 3226, blocks NPY inhibition of insulin secretion from, and inhibits ${ }^{125} \mathrm{I}-\mathrm{PYY}$ binding to, RIN 5AH cells. Northern blot analysis using a Y1-receptor specific probe shows that NPY Y1 re-
\end{abstract}

ceptors are expressed by RIN 5AH cells. Y5 receptors are not expressed in this cell line. Neuropeptide $Y$ inhibition of insulin secretion is blocked by incubation with pertussis toxin, implying that the effect is via a G-protein $\left(G_{i}\right.$ or $\left.G_{o}\right)$ coupled receptor. Neuropeptide $Y$ inhibits the activation of adenylyl cyclase by isoprenaline in RIN 5AH cell lysates, and the stimulation of cAMP by glucagon-like peptide-1 (7-36) amide (GLP-1). It also blocks insulin secretion stimulated by GLP-1, but not by dibutyryl cyclic AMP. Hence, we suggest that NPY inhibits insulin secretion from RIN 5AH cells via a Y1 receptor linked through $\mathrm{G}_{\mathrm{i}}$ to the inhibition of adenylyl cyclase. [Diabetologia (1998) 41: 1482-1491]

Keywords Neuropeptide Y, Y1 receptor, insulin secretion, insulinoma cells.
Received: 10 November 1997 and in final revised form: 16 June 1998

Corresponding author: D. M. Smith, ICSM Endocrine Unit at the Hammersmith Hospital, Imperial College School of Medicine, Du Cane Road, London, W12 0HH, UK

Abbreviations: NPY, Neuropeptide Y; PYY, peptide YY; PP, pancreatic polypeptide; [Pro $\left.{ }^{34}\right]-N P Y, N P Y$ analogue with proline substituted for isoleucine at position 34; NPY 3-36 and NPY 13-36, NPY fragments with the first two and twelve Nterminal amino acids removed respectively; Y1-Y6, NPY/ PYY/PP receptor subtypes; GTP- $\gamma$-S, guanosine 5 '-O-(3-thiotriphosphate); ATP- $\gamma$-S, adenosine $5^{\prime}$-O-(3-thiotriphosphate); FCS, fetal calf serum; GLP-1, glucagon like peptide 1 (7-36) $\mathrm{NH}_{2}$; HEPES, N-[2-hydoxyethyl]piperazine-N'-[2-ethanesulphonic acid]; DMEM, Dulbecco's modified Eagle's medium.
Insulin secretion from the beta cells of the pancreas is under many regulatory influences, including neuropeptide Y (NPY). This 36 amino acid peptide is one of the most widespread peptide messengers in the body [1]. Among its many actions, an inhibition of insulin secretion by NPY has been found in mouse [2], pig [3] rat [4-6] and human [7]. In the islets, most NPY can be found in sympathetic nerves [8] and a role in the sympathetic regulation of insulin secretion has therefore been suggested. Recently, we have shown the presence of messenger RNA for NPY in islets from rats treated with 6-hydroxydopamine to remove sympathetic inervation [9]. This is supported by reports from others $[10,11]$ and by work showing synthesis of NPY by clonal insulin-secreting cell lines $[9,12]$. These results suggest local production of NPY in the islet, and a paracrine or autocrine regulation of 
insulin secretion. In normal rat islets, NPY secretion decreases in a similar manner to glucagon following an increase in the glucose concentration [6]. In insulin resistant dexamethasone treated rats, however, islet NPY secretion followed a pattern more similar to insulin secretion, with a sixfold rise seen with increased glucose [6]. These results suggest a complicated system of NPY production in the islets and this is possibly mirrored by complexity in the response to NPY.

Neuropeptide Y, peptide YY (PYY) and pancreatic polypeptide (PP) form a family of peptides with similar structures. There are currently six recognised receptor subtypes for these peptides (Y1-Y6) [13-18]. The different subtypes of receptor for this family have been identified and characterised by their ability to bind NPY, PYY and PP fragments and analogues. The Y1 receptor binds with high affinity only full length NPY or full length analogues such as the NPY analogue $\left[\mathrm{Pro}^{34}\right] \mathrm{NPY}$ with proline substituted for isoleucine at position 34, and has reduced affinity for C-terminal fragments such as NPY fragments with the first twelve N-terminal amino acids removed (NPY 13-36). The Y2 receptor, in contrast to $\mathrm{Y} 1$, has a much higher affinity for C-terminal fragments than for substituted analogues such as $\left[\mathrm{Pro}^{34}\right]$ NPY.

A group of receptors sharing low affinity for PYY have been labelled y3 [19]. Peptide YY is reported to have similar effects to NPY on insulin secretion [20] and this receptor therefore seems unlikely to be involved in the effect of NPY on the beta cell. The recently cloned Y4 receptor $[17,21]$ is characterised by its high affinity for PP and the Y5 [14] and Y6 [15] receptors are both receptors with Y1-like profiles found in the hypothalamus. Although the Y6 receptor has been cloned from mouse genomic DNA, a physiological correlate has yet to be described and in a number of species the receptor has undergone a frame-shift mutation.

The mechanism of the inhibitory action of NPY on insulin secretion is not known. In many other systems NPY acts via the inhibitory GTP-binding protein (Gprotein), $\mathrm{G}_{\mathrm{i}}$, and inhibition of adenylyl cyclase [22-24]. In pancreatic perfusion studies, however, NPY inhibited secretion stimulated by dibutyryl cyclic AMP [25], suggesting that this effect might be distal to cyclic AMP generation. Alternative modes of action might include interaction with $\mathrm{K}^{+}$channels, to block membrane depolarisation (as seen with diazoxide, and with the neuropeptide galanin [26]), or interaction with $\mathrm{Ca}^{2+}$ channels [27].

To investigate the receptor and second messenger systems involved in the inhibition of insulin secretion by NPY we have used the clonal beta-cell line RIN $5 \mathrm{AH}$ [28]. Clonal cells were chosen for initial characterisation of this system because experiments with isolated islets are both difficult to do, and difficult to interpret, because of the confounding influence of multiple cell types. These intra-islet paracrine influences are important for the functioning of the normal islet, and therefore experiments with clonal cell lines, which are a model of individual cell types, do not tell the whole story. To understand the intra-islet interactions it is, however, first necessary to understand the actions and responses of the individual cell types involved. For this, clonal cell lines provide an invaluable tool. Clonal cell lines also have the disadvantage of being transformed. This often leads to phenotypes altered from the cells of which they are supposed to be models, and this should be born in mind when interpreting results obtained using them. RIN 5AH was chosen in preference to some other insulin secreting cell lines because of its glucose responsiveness (cf. RIN m5F, which is not glucose responsive but responds to other secretagogues such as glyceraldehyde). We have examined the NPY receptors present on this cell line and the inhibition of insulin secretion by NPY fragments and analogues.

\section{Materials and methods}

Peptides and iodination. The porcine sequence was used for all NPY fragments and analogues unless otherwise specified. NPY, NPY 3-36, NPY 13-36 and [Pro $\left.{ }^{34}\right]$-NPY were synthesised by P. Byfield (Haemostasis unit, Clinical Science Centre, Hammersmith Hospital, UK). Peptide YY was synthesised by IAF (Quebec, Canada). BIBP 3226 was kindly donated by Dr Karl Thomae GmBH (Biberach an der Riss, Germany). All cell culture reagents were supplied by Gibco (Gibco BRL, Life Technologies Ltd., Paisley, UK). All other materials were supplied by Sigma or Merck (both Poole, Dorset, UK) unless otherwise stated.

Porcine PYY was iodinated using the iodogen method as described previously [29]. Peptide $(5 \mathrm{nmol})$ was dissolved in $10 \mu \mathrm{l} 0.2 \mathrm{~mol} / \mathrm{l}$ phosphate buffer ( $\mathrm{pH} 7.2$ ) and added to a polypropylene tube containing $10 \mu \mathrm{g}$ 1,3,4,6-tetrachloro-3 $\alpha, 6 \alpha$ diphenylglycoluril (iodogen, Pierce, Rockford, Ill., USA), plus $37 \mathrm{MBq} \mathrm{Na}{ }^{125} \mathrm{I}$ (Amersham International, Amersham, Bucks., UK). This was incubated on ice for $5 \mathrm{~min}$ and products separated by reversed phase $\mathrm{C}_{18}$ HPLC (Waters Novapak column, Millipore, Milford, Mass., USA), developed with a $15-45 \%$ acetonitrile (v/v) water $0.05 \%$ trifluoroacetic acid (v/ v) gradient. Fractions $(1.5 \mathrm{ml})$ were collected and radioactive peaks assayed for receptor binding activity. Active fractions were aliquoted, freeze-dried and stored at $-20^{\circ} \mathrm{C}$. The specific activity of the radioligand was $27 \mathrm{~Bq} / \mathrm{fmol}$.

Cell culture. RIN 5AH cells from passage number 14 to 20 were maintained routinely in RPMI 1640 medium containing $5.5 \mathrm{mmol} / \mathrm{l}$ glucose and $5.5 \mathrm{mmol} / \mathrm{l}$ glutamine and supplemented with $10 \%$ fetal calf serum (FCS) (v/v) and antibiotics (penicillin $100 \mathrm{IU} / \mathrm{ml}$ and streptomycin $100 \mu \mathrm{g} / \mathrm{ml}$ ) [30]. Medium was changed every $48 \mathrm{~h}$ and cells passaged when they reached $70 \%$ confluence (approximately 7 days). In the same way SKN-MC cells (Dr. S. Legon, Dept. Metabolic Medicine, Hammersmith Hospital, ICSM), which are the de facto standard for investigation of Y1 receptors [31, 32], were grown routinely in $50 \%$ Dulbecco's modified Eagle's medium (DMEM) $/ 50 \%$ HAMS F12 medium, supplemented with $10 \%$ FCS and antibi- 
otics [33]. HEK 293 cells (Dr. S. Legon) were stably transfected with the NPY Y5 receptor cDNA according to the methods of Gerald et al. [14], and grown in DMEM with $10 \%$ FCS and antibiotics.

Insulin secretion experiments. RIN 5AH cells were grown as above in 24-well plates for $96 \mathrm{~h}$. Medium was replaced for $2 \mathrm{~h}$ before the start of the experiment with glucose free, FCS free medium. Cells were then incubated for $2 \mathrm{~h}$ in FCS free medium with $1.2 \mathrm{mmol} / \mathrm{l}$ glucose and test substances. The medium was then removed and stored at $-20^{\circ} \mathrm{C}$ for subsequent RIA. Dose response curves were constructed for NPY 1-36, NPY 3-36, NPY 13-36, [Pro $\left.{ }^{34}\right]-N P Y$ and BIBP 3226. The effect of NPY $(100 \mathrm{nmol} / \mathrm{l})$ on insulin secretion in the presence of glucagon like peptide (GLP)-1 (10 nmol/l), and dibutyryl cyclic AMP $(1 \mathrm{mmol} / \mathrm{l})$ (both in the presence of $1.2 \mathrm{mmol} / \mathrm{l}$ glucose) was tested. All secretion experiments were carried out in triplicate, and were repeated between 6 and 12 times.

To test the ability of pertussis toxin to inhibit the action of NPY on RIN 5AH cells, cells were preincubated for $2 \mathrm{~h}$ in glucose free, serum free RPMI 1640 medium containing $200 \mathrm{ng} / \mathrm{ml}$ pertussis toxin (Sigma Pode, UK). They were then exposed to medium containing combinations of glucose $(1.2 \mathrm{mmol} / \mathrm{l})$, pertussis toxin $(200 \mathrm{ng} / \mathrm{ml})$, NPY $(1 \mu \mathrm{mol} / \mathrm{l})$, and somatostatin $(1 \mu \mathrm{mol} / \mathrm{l})$. Medium was removed after $3 \mathrm{~h}$ and insulin was measured by radioimmunoassay (RIA).

Insulin radioimmunoassay. Culture medium was assayed in duplicate for insulin by an established RIA using porcine insulin standard and Glu5 antibody at a final dilution of 1:150,000 [6]. The assay had a detection limit of $2 \mathrm{fmol} /$ tube at $95 \%$ confidence limits. Both inter-assay and intra-assay variations were below $10 \%$.

Membrane preparation. Cell membranes were prepared by osmotic lysis and differential centrifugation as described previously [33]. Briefly, cells were lysed in $100 \mathrm{mls}$ of $1 \mathrm{mmol} / \mathrm{l} \mathrm{N}$ [2-hydoxyethyl]piperazine-N'-[2-ethanesulphonic acid] (HEPES) buffer ( $\mathrm{pH}$ 7.4) containing protease inhibitors (benzamidine $(100 \mu \mathrm{g} / \mathrm{ml})$, bacitracin $(100 \mu \mathrm{g} / \mathrm{ml})$, aprotinin $(30 \mu \mathrm{g} / \mathrm{ml})$, soya bean trypsin inhibitor $(10 \mu \mathrm{g} / \mathrm{ml})$, pepstatin $(0.5 \mu \mathrm{g} / \mathrm{ml})$, leupeptin $(0.5 \mu \mathrm{g} / \mathrm{ml})$, and antipain $(0.5 \mu \mathrm{g} / \mathrm{ml}))$ at $4{ }^{\circ} \mathrm{C}$. The lysate was centrifuged at $4{ }^{\circ} \mathrm{C}$ for $15 \mathrm{~min}$ at $3000 \mathrm{~g}$. The supernatant was then discarded and the pellet disrupted in $50 \mathrm{mmol} / \mathrm{l}$ HEPES ( $\mathrm{pH} 7.4$ ) with protease inhibitors and centrifuged again at $4{ }^{\circ} \mathrm{C}$ for $15 \mathrm{~min}$ at $3000 \mathrm{~g}$. The supernatant was then centifuged at $4{ }^{\circ} \mathrm{C}$ for $60 \mathrm{~min}$ at $48000 \mathrm{~g}$, and the resulting pellet resuspended in the same buffer to a final concentration of 2-4 $\mathrm{mg} / \mathrm{ml}$, as determined by biuret protein assay [34]. Aliquots were stored at $-80^{\circ} \mathrm{C}$ until use.

Receptor binding. Receptor binding was carried out as described previously [33]. Membranes (100 $\mu \mathrm{g}$ protein) were incubated with $\left.1000 \mathrm{~Bq}(75 \mathrm{pmol} / \mathrm{l}){ }^{125} \mathrm{I}\right]-\mathrm{PYY}$ in the presence or absence of unlabelled peptides as indicated. Binding was carried out in a final volume of $500 \mu \mathrm{l}$ assay buffer $(20 \mathrm{mmol} / \mathrm{l}$ HEPES pH 7.4, $5 \mathrm{mmol} / 1 \mathrm{CaCl}_{2}, 1 \mathrm{mmol} / \mathrm{l} \mathrm{MgCl}_{2}, 1 \%$ (w/v) bovine serum albumin) for $90 \mathrm{~min}$ at $30^{\circ} \mathrm{C}$. Bound and free label were then separated at $4^{\circ} \mathrm{C}$ by centrifugation for 2 min at $15000 \mathrm{~g}$. The pellet was resuspended in $1 \mathrm{ml}$ of ice-cold assay buffer and re-centrifuged. Bound ${ }^{125} \mathrm{I}-\mathrm{PYY}$ was then quantified in a $\gamma$-counter. Total specific binding was defined as the difference in counts between assays in the presence (non-specific) and absence (total) of $200 \mathrm{nmol} / \mathrm{l} \mathrm{NPY}$. Analysis of ${ }^{125} \mathrm{I}-\mathrm{PYY}$ binding experiments was carried out using ReceptorFit programs (Lundon Software Inc., Cleveland, Ohio, USA). Twosite and one-site curves were compared by $F$-test. Two-site curves were considered to be of a significantly better fit than one-site when $p$ was less than 0.05 .

Adenylyl cyclase activity. Cell lysates were made as described previously [33]. Briefly, confluent cultures of RIN 5AH cells grown in $75 \mathrm{~cm}^{2}$ flasks were washed with ice-cold phosphatebuffered saline and then with ice-cold $1 \mathrm{mmol} / \mathrm{l}$ Tris/HCl $(\mathrm{pH}$ 7.4) containing $2 \mathrm{mmol} / \mathrm{l}$ EDTA, pepstatin $(0.5 \mu \mathrm{g} / \mathrm{ml})$, leupeptin $(0.5 \mu \mathrm{g} / \mathrm{ml})$, and antipain $(0.5 \mu \mathrm{g} / \mathrm{ml})$. The cells were then allowed to lyse in $3 \mathrm{ml}$ of the same buffer for $15 \mathrm{~min}$ at $4{ }^{\circ} \mathrm{C}$ and then disrupted in a glass teflon homogeniser. Aliquots $(20 \mu \mathrm{l})$ of the lysate were incubated for $10 \mathrm{~min}$ at $25^{\circ} \mathrm{C}$ in a total volume of $100 \mu \mathrm{l}$ reaction mixture containing $25 \mathrm{mmol} / \mathrm{l} \mathrm{Tris} / \mathrm{HCl}$ (pH 7.4), 2 mmol/l MgCl, 1 mmol/l EDTA, 100 umol/l GTP, $100 \mu \mathrm{mol} / \mathrm{l}$ ATP, $1 \mathrm{mmol} / \mathrm{l}$ cyclic AMP, $20 \mathrm{mmol} / \mathrm{l}$ creatine phosphate, $2 \mathrm{mmol} / \mathrm{l}$ isobutyl methylxanthine, $20 \mu \mathrm{g}$ creatine kinase, $20 \mu \mathrm{g}$ myokinase, $1 \mu \mathrm{Ci}\left[\alpha_{-}{ }^{32} \mathrm{P}\right]$ ATP and $33 \mathrm{nCi}^{3} \mathrm{H}$ cyclic AMP (Amersham International) and, where indicated, various experimental agents. The reaction was stopped by the addition of $10 \mu \mathrm{l} 62.5 \%(\mathrm{v} / \mathrm{v})$ trichloroacetic acid, and insoluble matter separated by centrifugation $(15000 \mathrm{~g}, 3 \mathrm{~min})$. The supernatant was assayed for ${ }^{32} \mathrm{P}$-labelled cyclic AMP as described previously [35]. Assays were carried out with a replicate number of 6 , and were repeated at least three times.

Cyclic AMP measurement. RIN 5AH cells were grown on 24well plates as described for insulin secretion experiments. On the day of the experiment, medium was replaced with glucose-free and serum-free RPMI 1640. After $2 \mathrm{~h}$ preincubation, this was replaced with serum-free RPMI 1640 containing $1 \mathrm{mmol} / \mathrm{l}$ isobutylmethylxanthine, either no glucose or $1.2 \mathrm{mmol} / \mathrm{l}$ glucose and experimental agents. After $15 \mathrm{~min}$ this medium was removed, and $1 \mathrm{ml}$ acid ethanol $(70 \%$ ethanol in $0.05 \mathrm{~N} \mathrm{HCl}$ ) added to the cells. This was left overnight at $-20^{\circ} \mathrm{C}$ and then dried down by centrifugal evaporation in a Savant Speed-vac Plus (Life Sciences International, Basingstoke, Hants., UK). The residue was taken up in $300 \mu$ l assay buffer (50 mmol/l $\mathrm{CH}_{3} \mathrm{COONa}, 0.1 \% \mathrm{NaN}_{3}, 8 \mathrm{mmol} / \mathrm{l}$ EDTA, $\mathrm{pH}$ 6.2) and assayed using the NEN Flash Plate cAMP assay kit (NEN Life Sciences, Hounslow, UK).

Northern blot analysis. Total RNA was extracted using the guanidinium thiocyanate/phenol/chloroform method [36]. Poly $(\mathrm{A})^{+}$RNA was prepared from total RNA by oligo $\left(\mathrm{dT}_{12-18}\right)$ cellulose (Amersham Pharmacia Biotech, St. Albans, Herts., UK) chromatography [37]. Northern blot analysis was done as described previously [36,37]. Briefly, $50 \mu \mathrm{g}$ of poly (A) + RNA was size separated on a denaturing 3-(n-morpholino) propane-sulphonic acid (MOPS)/formaldehyde $1 \%$ agarose gel and transferred to a Hybond-N membrane (Amersham International). The RNA was fixed by baking at $80^{\circ} \mathrm{C}$ for $2 \mathrm{~h}$. Analysis of Y1 receptor mRNA was carried out using an oligonucleotide probe corresponding to nucleotides $465-489$ of the rat Y1 receptor sequence [38]. The probe was labelled using $\left[\alpha^{32} \mathrm{P}\right]$-dATP (Amersham International) and terminal transferase (Promega, Southampton, UK) and the blot was treated as described previously [36]. Briefly, the blot was hybridised with $2 \mathrm{ng} / \mathrm{ml}$ oligonucleotide probe in $5 \times \mathrm{SSC}$ $(1 \times \mathrm{SSC}=0.15 \mathrm{mmol} / \mathrm{l} \mathrm{NaCl}, 0.015 \mathrm{mmol} / \mathrm{l}$ Sodium Citrate, $\mathrm{pH} 7.0), \quad 10 \times$ Denhardts solution $(1 \times$ Denhardts solution $=0.02 \%$ ficoll, $0.02 \%$ polyvinylpyrrolidone, $0.02 \% \mathrm{BSA}$ fraction V), $20 \mathrm{mmol} / \mathrm{l} \mathrm{Na}_{3} \mathrm{PO}_{4}, 100 \mu \mathrm{g} / \mathrm{ml}$ herring sperm DNA, $7 \%$ sodium dodecyl sulphate and $10 \%$ dextran sulphate for $18 \mathrm{~h}$ at $55^{\circ} \mathrm{C}$. The blot was then washed in $1 \times \mathrm{SSC}, 1 \%$ sodium dodecyl sulphate for $30 \mathrm{~min}$ at $60^{\circ} \mathrm{C}$. Y 5 receptor mRNA was analysed using a cDNA probe corresponding to the entire coding region of the rat Y5 receptor sequence [14], labelled 


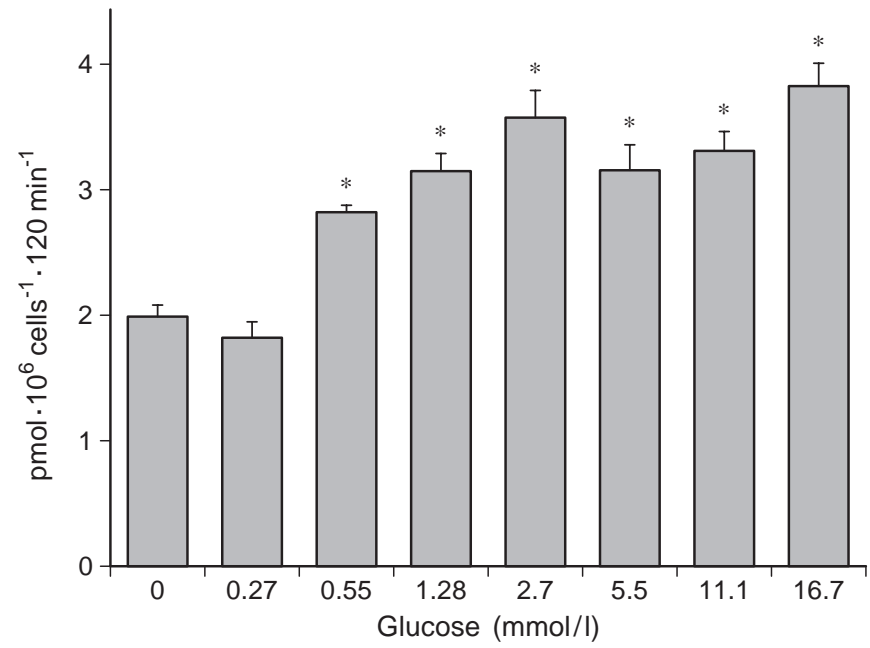

Fig. 1. Insulin secretion from RIN $5 \mathrm{AH}$ cells in response to glucose. ${ }^{*} p<0.05$ vs zero glucose. Results are the means \pm SEM of 6 experiments, each carried out in triplicate

by random primer extension using $\left[\alpha-{ }^{32} \mathrm{P}\right]-\mathrm{dCTP}$ and the Klenow fragment as described previously [37]. Briefly, hybridisation included $1 \mathrm{ng} / \mathrm{ml}$ probe in $50 \%$ formamide, $5 \times \mathrm{SSC}$, $5 \times$ Denhardts solution, $100 \mu \mathrm{g} / \mathrm{ml}$ herring sperm DNA and $10 \%$ dextran sulphate for $18 \mathrm{~h}$ at $42^{\circ} \mathrm{C}$. The blot was washed in $0.1 \times \mathrm{SSC}, 0.1 \%$ sodium dodecyl sulphate for $20 \mathrm{~min}$ at $60^{\circ} \mathrm{C}$.

\section{Results}

Insulin secretion. RIN 5AH cells secreted insulin in response to glucose in a dose dependent manner, with $1.2 \mathrm{mmol} / \mathrm{l}$ glucose giving maximum stimulation (Fig.1). Basal insulin secretion was $2.0 \pm 0.1 \mathrm{fmol}$. $10^{6}$ cells $^{-1} \cdot \mathrm{min}^{-1}$ and this was raised to $3.8 \pm 0.2$ fmol $\cdot 10^{6} \mathrm{cells}^{-1} \cdot \mathrm{min}^{-1}$ by maximum glucose stimulation (means \pm SEM of six individual experiments, each in triplicate). Neuropeptide $\mathrm{Y}$ is able to inhibit insulin secretion by $50.4 \pm 7.5 \%$, with an approximate $\mathrm{EC}_{50}$ of $0.1 \mathrm{nmol} / 1$ for this effect and [Pro $\left.{ }^{34}\right]$ NPY is almost as potent an inhibitor of insulin secretion in RIN 5AH as NPY itself (approximate $\mathrm{EC}_{50}=0.3 \mathrm{nmol} / \mathrm{l}$ ) (Fig. 2), suggesting that the peptide could be acting through a Y1-like receptor. Neuropeptide Y 13-36, was unable to inhibit insulin secretion at concentrations up to $1 \mu \mathrm{mol} / \mathrm{l}$ (Fig. $2 \mathrm{~d}$ ), further supporting the involvement of a Y1-like receptor. Neuropeptide Y 3-36 inhibits insulin secretion with a potency about 18-times lower than NPY 1-36 (Fig. $2 \mathrm{c}$, approximate $\mathrm{EC}_{50}=1.8 \mathrm{nmol} / \mathrm{l}$ ), again fitting the expected profile for the Y1 receptor. The Y1 receptor antagonist BIBP 3226 was able to block the inhibition of glucose stimulated insulin secretion by 10 $\mathrm{nmol} / \mathrm{l} \mathrm{NPY} \mathrm{(Fig.} 2 \mathrm{f}$, approximate $\mathrm{EC}_{50}=3.2 \mu \mathrm{mol} / \mathrm{l}$ ) but had no effect itself on glucose stimulated insulin secretion (Fig. 2e). Pertussis toxin $(200 \mathrm{nmol} / \mathrm{l})$ is able to completely block the inhibition of insulin se-

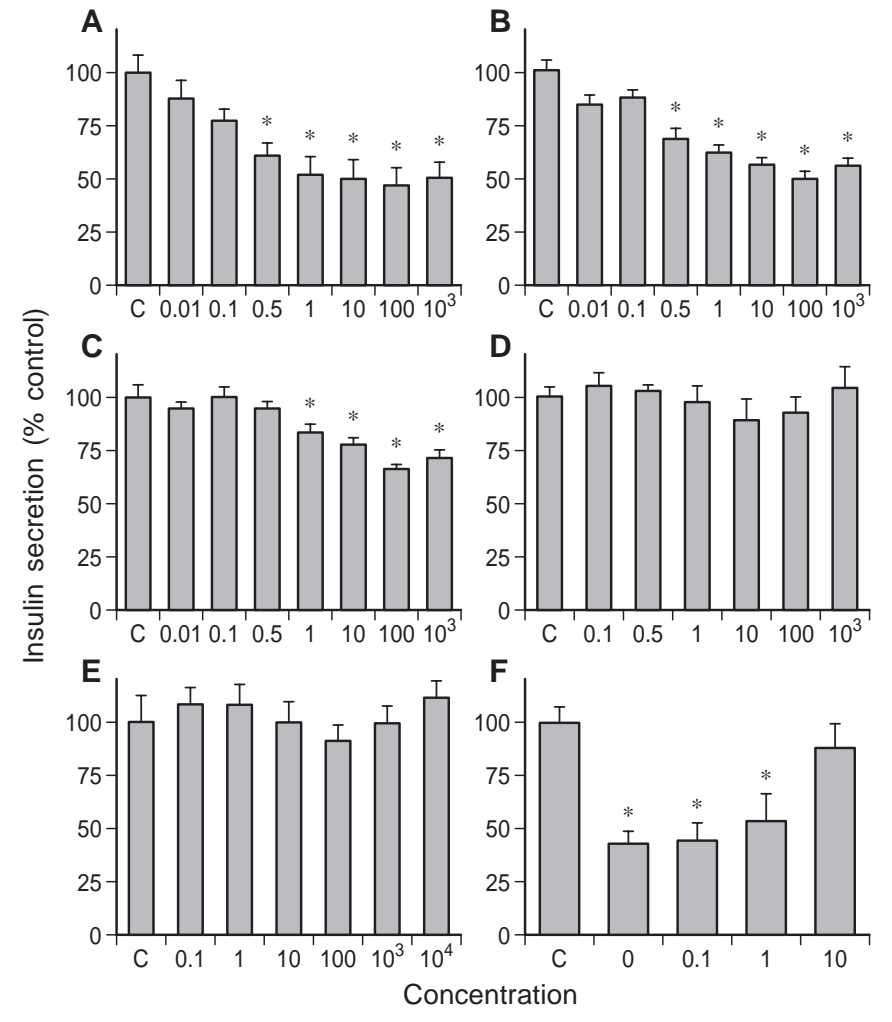

Fig. 2A-F. Insulin secretion from RIN 5AH cells, as a percentage of maximum glucose response. The dose response curves for the inhibition of glucose stimulated insulin secretion by NPY 1-36(A), [Pro $\left.{ }^{34}\right]$-NPY (B), NPY 3-36 (C), and NPY 13-36 (D). E shows the lack of effect of BIBP 3226 on stimulated insulin secretion. $\mathbf{F}$ is the dose response curve for antagonism of the effect of $10 \mathrm{nmol} / \mathrm{l}$ NPY by BIBP 3226. Concentrations of treatment are in nanomolar for $\mathbf{A}, \mathbf{B}, \mathbf{C}, \mathbf{D}$ and $\mathbf{E}$, and in $\mu$ molar for $\mathbf{F} . * p<0.05$ vs glucose stimulated secretion. Results are the means \pm SEM of 6-12 experiments, each carried out in triplicate

cretion by NPY $(1 \mu \mathrm{mol} / \mathrm{l})$ and the positive control, somatostatin $(1 \mu \mathrm{mol} / \mathrm{l})$ (Fig. 3$)$.

Glucagon like peptide-1 $(100 \mathrm{nmol} / \mathrm{l})$ potentiates glucose-stimulated insulin secretion from RIN $5 \mathrm{AH}$ cells $\left(6.4 \pm 0.4 \mathrm{fmol} \cdot 10^{6} \mathrm{cells}^{-1} \cdot \mathrm{min}^{-1}\right.$ in $1.2 \mathrm{mmol} / 1$ glucose control, $26.4 \pm 0.9 \mathrm{fmol} \cdot 10^{6} \mathrm{cells}^{-1} \cdot \mathrm{min}^{-1}$ in the presence of $100 \mathrm{nmol} / \mathrm{l} \mathrm{GLP}-1,410 \%$ increase, $p<0.01$ vs glucose control, $n=5$ each carried out in triplicate) (Fig. 4). Neuropeptide Y (100 nmol/l) is able to completely block this effect (GLP$1+\mathrm{NPY}=92 \pm 5 \%$ of $1.2 \mathrm{mmol} / \mathrm{l}$ glucose control, $p<0.01$ vs GLP alone, $n=5$ experiments each carried out in triplicate) as well as insulin secretion in the absence of GLP-1 (NPY alone $=31 \pm 3 \%$ of $1.2 \mathrm{mmol} / 1$ glucose control, $p<0.05$ vs glucose control). Dibutyryl cyclic AMP causes a dose dependent increase in insulin secretion, with $1 \mathrm{mmol} / \mathrm{l}$ being the lowest concentration to cause an increase $(4.0 \pm 0.2$ $\mathrm{fmol} \cdot 10^{6} \mathrm{cells}^{-1} \cdot \mathrm{min}^{-1}$ in $1.2 \mathrm{mmol} / 1$ glucose control, $5.8 \pm 0.3 \mathrm{fmol} \cdot 10^{6} \mathrm{cells}^{-1} \cdot \mathrm{min}^{-1}$ in the presence of $1 \mathrm{mmol} / \mathrm{l}$ dibutyryl cyclic AMP, $140 \%$ increase, 


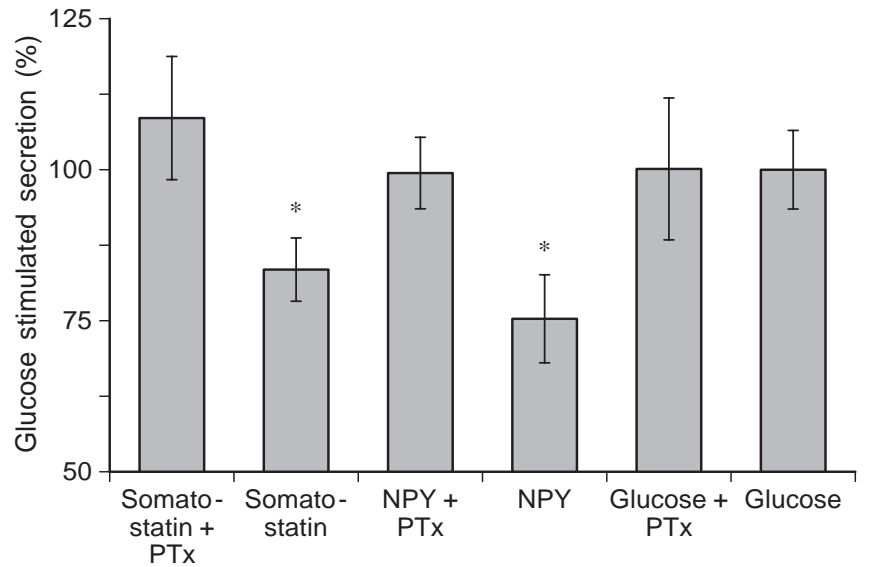

Fig.3. The effect of pertussis toxin (PTx, $200 \mathrm{ng} / \mathrm{ml}$ ) on NPY and somatostatin inhibition of insulin secretion from RIN $5 \mathrm{AH}$. Cells were preincubated with pertussis toxin for $2 \mathrm{~h}$ and then incubated with pertussis toxin and peptide for a further $2 \mathrm{~h}$. Somatostatin is included as a positive control. Results are expressed as percentage of insulin secreted in response to $1.2 \mathrm{mmol} / \mathrm{l}$ glucose (i.e. difference between zero glucose and $5.5 \mathrm{mmol} / \mathrm{l}$ glucose). The results shown are the means \pm SEM of 3 experiments, each carried out with 6 replicates

$p<0.01$ vs control) (Fig.4). A concentration of $10 \mathrm{mmol} / \mathrm{l}$ caused a further increase $(6.8 \pm 0.3$ $\mathrm{fmol} \cdot 10^{6} \mathrm{cells}^{-1} \cdot \mathrm{min}^{-1}, 170 \%$ increase, $p<0.01$ vs control). The ability of NPY to inhibit dibutyryl cyclic AMP (1 mmol/l) stimulated insulin secretion was investigated (Fig. 4c). In this experiment, dibutyryl cyclic AMP was again found to potentiate glucose stimulated insulin secretion from RIN 5AH cells $(5.6 \pm 0.2$ $\mathrm{fmol} \cdot 10^{6} \mathrm{cells}^{-1} \cdot \mathrm{min}^{-1}$ in $1.2 \mathrm{mmol} / \mathrm{l}$ glucose control, $12.7 \pm 0.5 \mathrm{fmol} \cdot 10^{6} \mathrm{cells}^{-1} \cdot \mathrm{min}^{-1}$ in the presence of $1 \mathrm{mmol} / \mathrm{l}$ dibutyryl cyclic AMP, 230\% increase, $p<0.01$ vs glucose control, $n=5)$. Neuropeptide $\mathrm{Y}$ $(100 \mathrm{nmol} / \mathrm{l})$ did not inhibit this action $(200 \pm 10 \%$ of $1.2 \mathrm{mmol} / \mathrm{l}$ glucose control, $p>0.05, n=5$ ).

Binding of ${ }^{125} \mathrm{I}-\mathrm{PYY}$ to RIN $5 \mathrm{AH}$ cell membranes. Binding experiments with RIN $5 \mathrm{AH}$ membranes consistently gave greater than $50 \%$ specific binding $(66.7 \pm 3.4 \%, n=10)$. Binding of increasing concentrations of ${ }^{125} \mathrm{I}-\mathrm{PYY}$ to RIN 5AH membranes showed a single, saturable binding site with a $\mathrm{K}_{\mathrm{D}}=395 \pm 72$ $\mathrm{pmol} / 1$ and $\mathrm{B}_{\max }=286 \pm 47 \mathrm{fmol} / \mathrm{mg}$ protein $(n=3)$ (Fig. 5). Inset in this figure is a scatchard analysis of binding data to verify the single site model, but is not used for calculation of $\mathrm{B}_{\max }$ and $\mathrm{K}_{\mathrm{D}}$, since it is less accurate than the non-linear method used [39]. Binding of ${ }^{125}$ I-PYY was inhibited in a dose-dependent manner by the non-hydrolysable GTP analogue, guanosine 5 '-O-(3-thiotriphosphate) (GTP- $\gamma$-S, approximate $\quad \mathrm{IC}_{50} \sim 3 \mu \mathrm{mol} / 1$, maximum inhibition $=95.5 \pm 4 \%)$, but not by adenosine 5 '-O-(3thiotriphosphate) (ATP- $\gamma$-S, IC $\left._{50}>100 \mu \mathrm{mol} / \mathrm{l}\right)$, suggesting a requirement for guanine nucleotides, and hence G-protein linkage of the receptor (Fig. 6). The
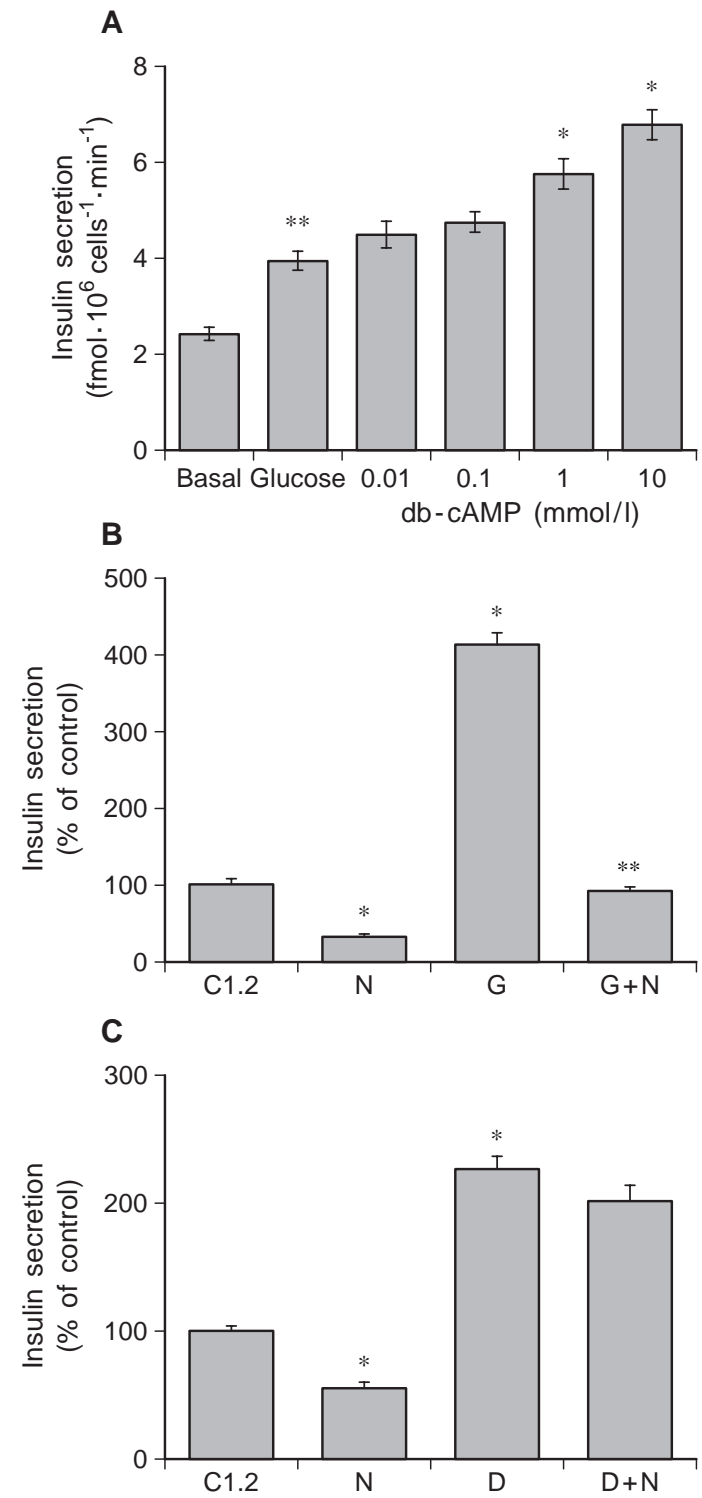

Fig. 4. A The effect of dibutyryl-cyclic AMP on insulin secretion from RIN 5AH cells. The lowest effective dose was $1 \mathrm{mmol} / \mathrm{l}$, and this was used for subsequent experiments. The results shown are the means \pm SEM of 3 experiments each carried out in quadruplicate. $* * p<0.005$ vs basal secretion; $* p<0.01$ vs glucose stimulated insulin secretion. The effect of NPY (100 nmol/l) on B GLP-1 (100 nmol/l) and C dibutyrylcyclic AMP (1 mmol/l) stimulated insulin secretion from RIN 5AH cells. $* p<0.01$ vs $1.2 \mathrm{mmol} / 1$ glucose control, $* * p<0.01$ vs GLP-1). C1.2 = control $(1.2 \mathrm{mmol} / \mathrm{l}$ glucose alone $) . \mathrm{N}=100$ nmol/l NPY, G = 100 nmol/l GLP-1, G + N = 100 nmol/l GLP$1+100 \mathrm{nmol} / \mathrm{l} \mathrm{NPY}, \mathrm{D}=1 \mathrm{mmol} / \mathrm{l}$ dibutyryl cyclic AMP, $\mathrm{D}+\mathrm{N}=1 \mathrm{mmol} / \mathrm{l}$ dibutyryl cyclic AMP + $100 \mathrm{nmol} / \mathrm{l} \mathrm{NPY}$. The results shown are the means \pm SEM of 6 experiments, each carried out in triplicate

ability of NPY fragments and analogues to compete for ${ }^{125}$ I-PYY binding sites was examined in equilibrium competition binding experiments. Competition curves were constructed using NPY $\left(\mathrm{IC}_{50}=0.14 \pm\right.$ $0.025 \mathrm{nmol} / \mathrm{l}), \quad \mathrm{PYY} \quad\left(\mathrm{IC}_{50}=0.45 \pm 0.15 \mathrm{nmol} / \mathrm{l}\right)$, $\left[\mathrm{Pro}^{34}\right]-\mathrm{NPY}\left(\mathrm{IC}_{50}=0.34 \pm 0.17 \mathrm{nmol} / \mathrm{l}\right), \mathrm{NPY} 3-36$ 


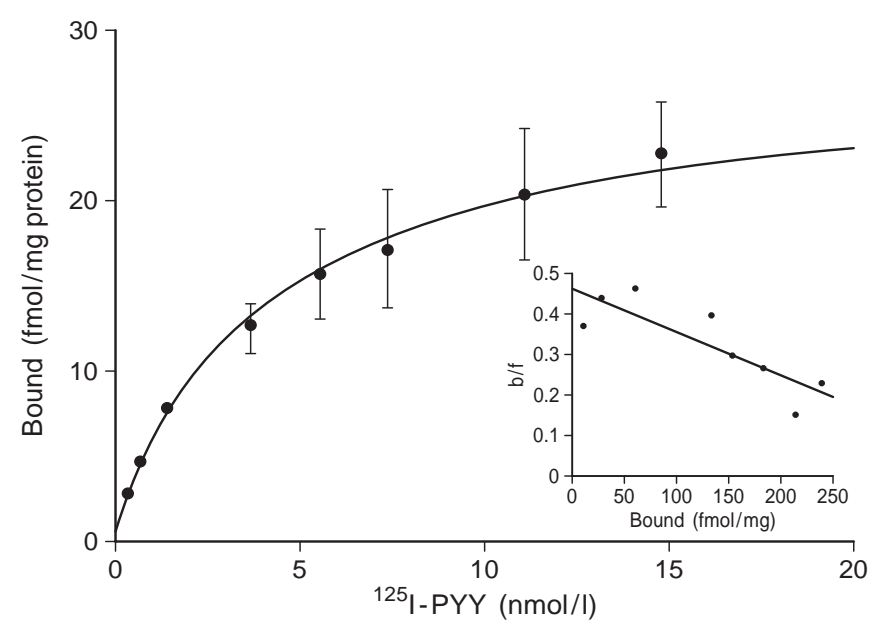

Fig. 5. Saturation binding of ${ }^{125} \mathrm{I}-\mathrm{PYY}$ to RIN $5 \mathrm{AH}$ cell membranes. Cells were incubated with increasing concentrations of ${ }^{125} \mathrm{I}-\mathrm{PYY}$ in the presence (non-specific binding) or absence (total binding) of $200 \mathrm{nmol} / \mathrm{l}$ NPY. Specific binding is shown and was calculated as the difference between total and nonspecific binding. $\mathrm{K}_{\mathrm{D}}$ and $\mathrm{B}_{\max }$ were calculated by non-linear regression analysis. Inset is Scatchard analysis of the same data [45], used to visually check one-site binding. Mean and SEM are calculated from 3 experiments

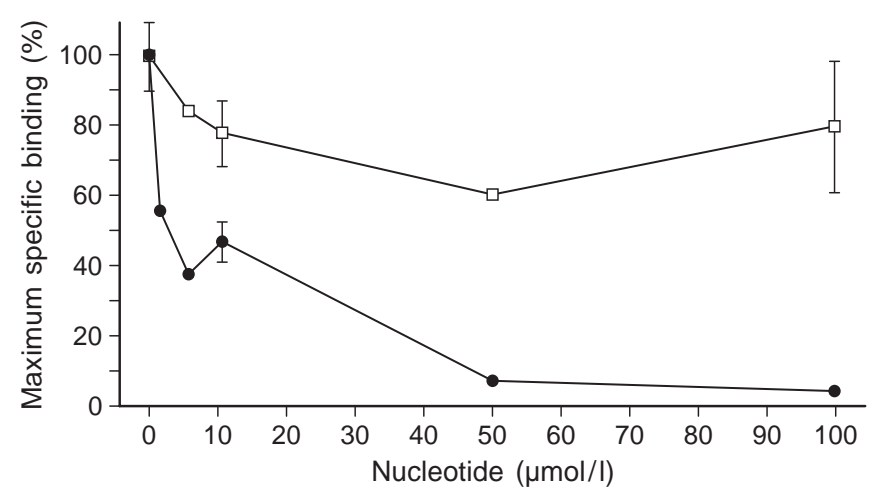

Fig. 6. The effect of GTP- $\gamma-\mathrm{S}(\mathbf{O})$ and ATP- $\gamma-\mathrm{S}(\square)$ on ${ }^{125} \mathrm{I}-$ PYY binding to RIN 5AH cell membranes. Membranes were incubated in the presence of increasing nucleotide concentration, in the presence (non-specific binding) or absence (total binding) of $200 \mathrm{nmol} / \mathrm{l} \mathrm{NPY}$. Specific binding was calculated as the difference between total and non-specific binding. Only specific binding is shown for the sake of clarity. Total and non-specific binding were carried out in triplicate, and the result of a representative experiment is shown here

$\left(\mathrm{IC}_{50}=0.98 \pm 0.16 \mathrm{nmol} / \mathrm{l}\right)$, and NPY 13-36 $\left(\mathrm{IC}_{50}=\right.$ $17 \pm 4 \mathrm{nmol} / \mathrm{l})$. These experiments show a receptor with a Y1-like profile, with ligands showing the order of potency NPY $>\left[\mathrm{Pro}^{34}\right]-\mathrm{NPY}=\mathrm{PYY}>\mathrm{NPY}$ 3-36>> NPY 13-36. The specific Y1 antagonist, BIBP 3226 bound to RIN 5AH cell membranes with an $\mathrm{IC}_{50}$ of $37 \mathrm{nmol} / \mathrm{l}$ (Fig. 7 ).

Adenylyl cyclase activity. To measure the inhibition of adenylyl cyclase, RIN 5AH cell lysates were incubated with isoprenaline to stimulate adenylyl cyclase ac-

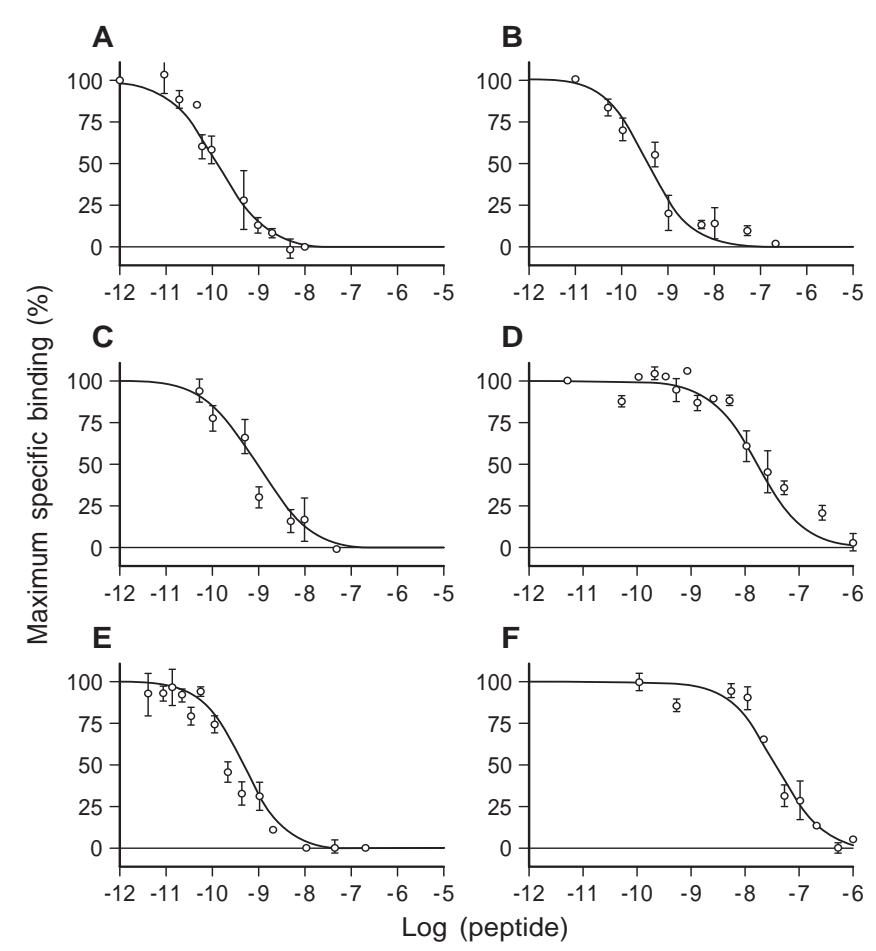

Fig. 7A-F. Competition for ${ }^{125} \mathrm{I}-\mathrm{PYY}$ binding to RIN $5 \mathrm{AH}$ membranes by NPY 1-36 (A), [Pro34]-NPY (B), NPY 3-36 (C), NPY 13-36 (D), PYY (E) and BIBP 3226 (F). IC I0 $_{50}$ values were calculated by non-linear regression analysis. Each curve is the average of three curves carried out in triplicate. The means \pm SEM of 3 experiments is shown here

tivity. Isoprenaline $(10 \mu \mathrm{mol} / \mathrm{l})$ gave a robust, but not maximum, stimulation $(242 \pm 8 \%$ vs control, $p<0.05$, results not shown), and hence this concentration was used for further experiments. Neuropeptide $\mathrm{Y}(1 \mu \mathrm{mol} / \mathrm{l}, 10 \mu \mathrm{mol} / \mathrm{l})$ was able to completely inhibit isoprenaline stimulated adenylyl cyclase activity $(113 \pm 4 \%$ of control and $93 \pm 9 \%$ of control respectively, $p<0.05$ vs isoprenaline) (Fig. 8$)$. It (10 $\mu \mathrm{mol} / \mathrm{l})$ produced a small but significant reduction in basal adenylyl cyclase activity $(60 \pm 3 \%$ of control, $p<0.05$ vs control). Somatostatin $(10 \mu \mathrm{mol} / 1)$, used as a positive control, reduced isoprenaline induced adenylyl cyclase activity by $70 \%(159 \pm 8 \%$ of control, $p<0.05$ vs isoprenaline) but had no effect on basal activity ( $97 \pm 14 \%$ control, $p>0.05)$.

Cyclic AMP measurement in whole cells. Glucagon like peptide at a concentration of $100 \mathrm{nmol} / \mathrm{l}$ was found to increase cAMP production in RIN 5AH cells $\left(0.42 \pm 0.04 \mathrm{pmol} \cdot 10^{6} \mathrm{cells}^{-1} \cdot \mathrm{min}^{-1}\right.$ in basal control, $0.84 \pm 0.09 \mathrm{pmol} \cdot 10^{6} \mathrm{cells}^{-1} \cdot \mathrm{min}^{-1}$ in GLP-1 stimulated, $p<0.01)$. Neuropeptide $\mathrm{Y}$ was able to inhibit this stimulation, with $100 \mathrm{nmol} / \mathrm{l}$ being the lowest effective dose $\left(0.7 \pm 0.07 \mathrm{pmol} \cdot 10^{6} \mathrm{cells}^{-1} \cdot \mathrm{min}^{-1}, p<0.01\right.$ vs GLP-1 alone), and $1 \mu \mathrm{mol} / 1$ completely removing the effect of GLP-1 $\left(0.44 \pm 0.09 \mathrm{pmol} \cdot 10^{6} \mathrm{cells}^{-1} \cdot \mathrm{min}^{-1}\right.$, not significantly different from basal) (Fig. 9). 


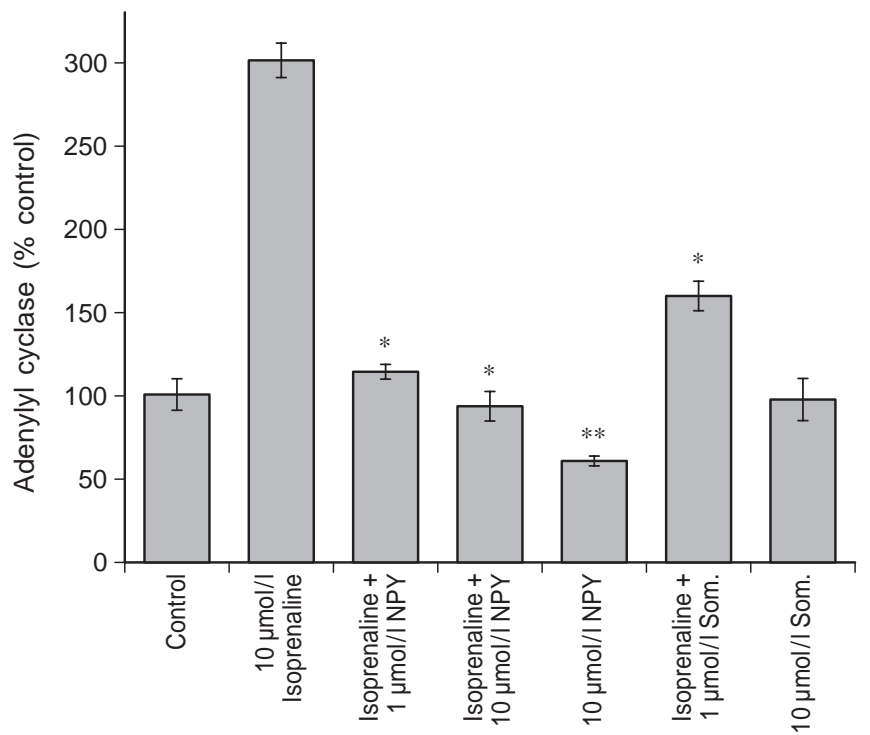

Fig.8. Adenylyl cyclase activity in RIN 5AH cell-lysates. Isoprenaline stimulates adenylyl cyclase activity and this is inhibited by NPY $(1 \mu \mathrm{mol} / 1,10 \mu \mathrm{mol} / \mathrm{l})$ and somatostatin (Som, $10 \mu \mathrm{mol} / \mathrm{l})$. Somatostatin is included as a positive control. Somatostatin had no effect on basal adenylyl cyclase activity. $* p<0.05$ vs isoprenaline control; ** $p<0.05$ vs saline control. Results shown are the means \pm SEM of 3 experiments carried out with 9 replicates

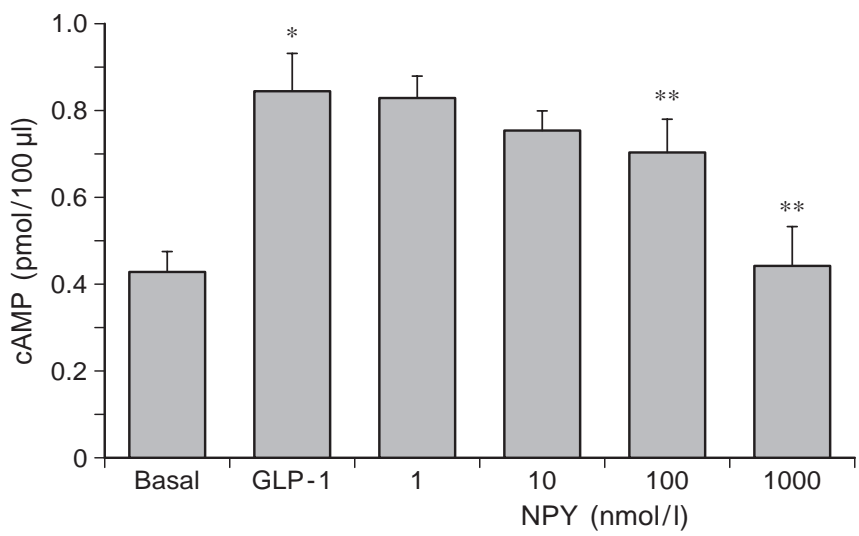

Fig. 9. Cyclic AMP measurement in whole cells. The effect of NPY on GLP-1 (7-36) $\mathrm{NH}_{2}$-stimulated accumulation of cAMP in RIN 5AH cells was measured by RIA. NPY is shown to dose-dependently inhibit the effect of GLP-1 (7-36) $\mathrm{NH}_{2}$. $* p<0.001$ vs basal cAMP; $* * p<0.001$ vs GLP-1 alone. Results shown are means \pm SEM of 3 experiments each carried out in quadruplicate

Northern blot analysis. Northern blot analysis of RIN $5 \mathrm{AH}$ and SK-N-MC cell poly (A) ${ }^{+}$RNA showed single bands of comparable size in both lanes when probed with an oligo probe specific for the Y1 receptor (Fig. 10a). The bands are not of identical size but ran at a position in keeping with the reported size of the cloned Y1 receptor of 3.5 kilobases (for the human receptor) [13] and 4 kilobases (for the rat) [38]. When poly $(\mathrm{A})^{+}$RNA from RIN $5 \mathrm{AH}$ was probed

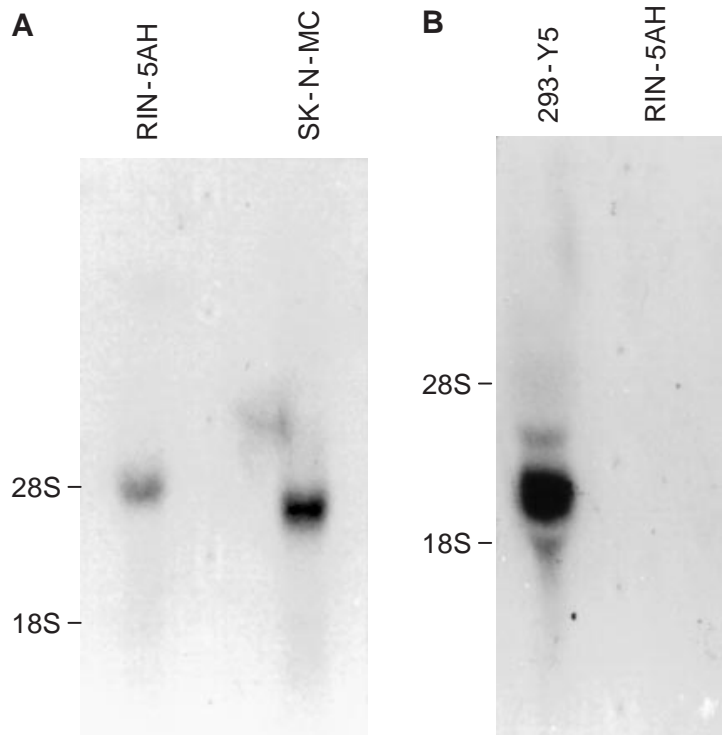

Fig. 10A, B. Northern blot analysis of poly- $\mathrm{A}^{+}$RNA from RIN $5 \mathrm{AH}$ in comparison $\mathbf{A}$ with SK-N-MC, probed with a Y1 specific probe and $\mathbf{B}$ with HEK 293 stably expressing Y5 receptors, and probed with a Y5 specific probe. $18 \mathrm{~S}$ and $28 \mathrm{~S}$ ribosomal RNA bands are used as size markers

with a specific probe for the NPY Y5 receptor, no band was visible. A clear band was seen when poly (A) ${ }^{+}$RNA from HEK 293 cells stably expressing rat NPY Y5 receptors was similarly probed (Fig. 10).

\section{Discussion}

Neuropeptide Y has been shown to inhibit glucosestimulated insulin secretion in vivo $[9,10]$ in isolated rat islets [6] and in clonal insulinoma cell lines [9, 12]. The receptor with which it interacts, and the second messenger system by which it affects insulin secretion have not, however, been identified. In this paper we show that in the insulinoma cell line, RIN $5 \mathrm{AH}, \mathrm{NPY}$ interacts with the NPY Y1 receptor and inhibits insulin secretion via a reduction in adenylyl cyclase activity.

Receptor binding indicated that a single population of NPY binding sites was present on RIN 5AH cell membranes. Non-linear regression analysis was carried out on the data derived from saturation experiments incubating RIN 5AH membranes with different concentrations of ${ }^{125}$ I-PYY. Statistical comparison of the goodness of fit of one-site and two-site models suggested that the one-site fit was better, and therefore, that either a single class of receptor was present, or that a number of classes were present all with similar affinities for ${ }^{125}$ I-PYY. The ligand profile of this receptor was investigated using competition curves. Non-linear regression analysis, again suggest- 
ed a single population of binding site for each of the peptides tested.

Competition curves generated using ${ }^{125}$ I-PYY binding to RIN 5AH membranes showed a Y1-like profile, with $\left[\mathrm{Pro}^{34}\right]-\mathrm{NPY}$ having a high affinity $\left(\mathrm{IC}_{50} \sim 0.3 \mathrm{nmol} / \mathrm{l}\right)$, and NPY 13-36 binding only in the mid-nanomolar range $\left(\mathrm{IC}_{50} \sim 17 \mathrm{nmol} / \mathrm{l}\right)$. The rank order of binding seen is NPY $>\left[\mathrm{Pro}^{34}\right]-\mathrm{NPY}=$ PYY > NPY 3-36 > NPY 13-36. Insulin secretion experiments on RIN 5AH cells show that NPY (approximate $\mathrm{EC}_{50}=0.1 \mathrm{nmol} / \mathrm{l}$ ), $\left[\mathrm{Pro}^{34}\right]$-NPY (approximate $\mathrm{EC}_{50}=0.3 \mathrm{nmol} / \mathrm{l}$ ), and NPY 3-36 (approximate $\mathrm{EC}_{50}=1.8 \mathrm{nmol} / \mathrm{l}$ ), all inhibited glucose-stimulated insulin secretion. The rank order of potency matches that of receptor affinity, with $\mathrm{NPY}>\left[\mathrm{Pro}^{34}\right]$ NPY $>$ NPY 3-36 > > NPY 13-36. The potency of NPY 3-36 seems slightly higher than might be expected at the Y1 receptor, and might suggest an activation profile more similar to the Y5 receptor. We have reported previously that in SK-N-MC cells, which express the Y1 receptor, NPY 3-36 has an affinity about 35 times lower than NPY 1-36 [33], whereas, at the Y5 receptor, NPY 1-36 and NPY 3-36 are reported to be virtually equipotent [14]. Although, in RIN 5AH cells, the affinity of NPY 3-36 is only 7 times lower than that of NPY 1-36 and its potency in inhibiting insulin secretion about 18 times lower than NPY 1-36, the profile is still more similar to the Y1 receptor than to the Y5 receptor. The difference between the binding affinity of NPY 13-36 to RIN 5AH NPY receptors and its potency on inhibition of insulin secretion suggests that it may bind to the receptor but with low efficacy.

Although these findings suggest that the Y1 receptor mediates the effect of NPY at the RIN 5AH cell, it remains a possibility that the Y5 receptor, which has a Y1-like binding profile, rather than the authentic Y1 is present. To test this, the ability of BIBP 3226 to inhibit the actions of NPY was investigated. BIBP 3226 is an antagonist at the Y1 receptor, and is reported not to bind to any other NPY receptor so far described including the Y5 receptor [14]. This antagonist blocks the inhibition by NPY of insulin secretion from RIN 5AH cells but has no effect on basal insulin secretion and binds to the NPY receptor on RIN $5 \mathrm{AH}$ cell membranes. The lack of effect of the antagonist on basal secretion suggests that there is no tonic activation of NPY receptors on these cells. In keeping with this, we were not able to observe any NPY-like immunoreactivity in medium in which RIN 5AH cells have been grown using a specific radioimmunoassay (results not shown). This is further evidence that the receptor mediating the inhibition by NPY of insulin secretion from RIN 5AH cells is the Y1 receptor and suggests that the Y5 receptor is not involved. Northern blot analysis shows two similarly sized bands in RIN 5AH and SK-N-MC cell polyA ${ }^{+}$RNA when probed with an oligo-probe for the Y1 receptor. That the two bands are not identical in size is not surprising since RIN 5AH is a rat cell line, whereas SK-N-MC is a human cell line, and since the rat and human Y1 mRNA s have been shown to be of different sizes ( $\mathrm{rat}=4 \mathrm{~kb}$ [38], human $=3.5 \mathrm{~kb}$ [13]). Northern blot analysis was not able to show expression of the Y5 receptor by RIN $5 \mathrm{AH}$ cells.

The ability of GTP- $\gamma$-S, but not ATP- $\gamma$-S, to completely block the specific binding of ${ }^{125} \mathrm{I}-\mathrm{PYY}$ to RIN $5 \mathrm{AH}$ membranes suggests that the receptor is G-protein linked, and the ability of pertussis toxin to block NPY's inhibition of insulin secretion further supports this. This latter effect suggests that NPY receptors in RIN 5AH cells are most likely coupled to $G_{i}$, or $G_{0}$. NPY has been shown to be coupled to these GTPbinding proteins (G-proteins) in a number of systems $[22,40]$. Evidence from other NPY systems would suggest that the most likely effector system to be activated by the receptor-G-protein complex is inhibition of adenylyl cyclase activity.

We have shown that NPY receptors in RIN 5AH cells are indeed linked to inhibition of this system, by directly measuring adenylyl cyclase activity and showing inhibition of GLP-1 (7-36) $\mathrm{NH}_{2}$ stimulated cAMP production in whole cells. Other experiments provide direct evidence that NPY inhibits insulin secretion by inhibiting adenylyl cyclase. Glucagon like peptide- 1 increases insulin secretion by increasing adenylyl cyclase activity and cyclic AMP [13]. Neuropeptide $\mathrm{Y}$ is able to completely block this effect, presumably by preventing stimulation of adenylyl cyclase. Dibutyryl cyclic AMP, on the other hand, stimulates insulin secretion through the same mechanisms as cyclic AMP but bypasses the requirement for adenylyl cyclase. Neuropeptide $\mathrm{Y}$ is not able to reduce insulin secretion stimulated by this agent, even though the dose of dibutyryl cAMP used produced a less than maximum stimulation of insulin secretion. This could suggest that NPY has no important effects distal to increased cyclic AMP, at least in RIN 5AH cells.

Taken together these experiments represent strong evidence that, in RIN 5AH cells, NPY inhibits insulin secretion via inhibition of adenylyl cyclase activation. There is, however, evidence from the literature suggesting that inhibition of adenylyl cyclase activity is possibly not the sole means by which NPY inhibits insulin secretion. For instance, in the perfused rat pancreas NPY is reported to inhibit insulin secretion in the presence of dibutyryl cyclic AMP [25]. PYY is reported to have similar effects in perifused mouse islets [41]. In this study PYY is reported to have no effect on protein kinase $\mathrm{C}$-stimulated insulin secretion, or on intracellular calcium or potassium efflux. In agreement with our findings, this paper reported a reduction in glucose stimulated cyclic AMP concentrations by PYY. The whole pancreas or islet are both far more complex systems than that which 
we are examining here, and it is possible that in these system, other factors and other effects of NPY cloud the results.

Additionally, it is not thought that raised adenylyl cyclase activity is a major factor in the stimulation of insulin secretion by glucose [42]. Our results strongly suggest that NPY does inhibit adenylyl cyclase activity and, that by doing so, it inhibits the increase in insulin secretion seen following GLP-1 treatment. It has also been reported that, in the dog, PYY is able to inhibit insulin secretion stimulated by gastric inhibitory polypeptide [43], another peptide known to stimulate insulin secretion by raising cyclic AMP concentrations [44]. It clearly remains possible that NPY inhibits insulin secretion stimulated by glucose by a means other than inhibition of adenylyl cyclase activity. At least in the RIN 5AH cell, inhibition of adenylyl cyclase activity appears an important mechanism by which NPY inhibits glucose-stimulated insulin secretion. It remains to be further investigated whether this system is equally important in the islet itself.

In summary, RIN 5AH cells express a single group of NPY receptors, with a Y1-like ligand-binding profile. This profile is similar to that seen for the inhibition of insulin secretion. The specific Y1 antagonist, BIBP 3226 blocks the inhibition of insulin secretion by NPY. The RIN 5AH cells express Y1 receptor mRNA, but not Y5 receptor mRNA. This receptor appears to inhibit insulin secretion by $\mathrm{G}_{\mathrm{i}}$-mediated inhibition of adenylyl cyclase activity.

Acknowledgements. D. G. Morgan received a UK Medical Research Council studentship during the course of this work. Thanks to James Gardiner for provision of Y5 expressing HEK 293 cell poly A ${ }^{+}$RNA. Thanks to Peter Byfield, Emma Stanton and Wendy Callinan for peptide synthesis services.

\section{References}

1. Polak JM, Bloom SR (1984) Regulatory peptides - the distribution of two newly discovered peptides: PHI and NPY. Peptides 5 [Suppl 1]:79-89

2. Pettersson M, Ahren B, Lundquist I, Bottcher G, Sundler F (1987) Neuropeptide Y: intrapancreatic neuronal localization and effects on insulin secretion in the mouse. Cell Tissue Res 248: 43-48

3. Ahren B, Martensson H, Falck B (1991) Effects of neuropeptide $\mathrm{Y}$ on insulin and glucagon secretion in the pig. Neuropeptides 20: 49-55

4. Pettersson M, Ahren B (1990) Insulin secretion in rats: effects of neuropeptide $\mathrm{Y}$ and noradrenaline. Diabetes Res 13: $35-42$

5. Moltz JH, McDonald JK (1985) Neuropeptide Y: direct and indirect action on insulin secretion in the rat. Peptides 6: 1155-1159

6. Wang ZL, Bennet WM, Wang RM, Ghatei MA, Bloom SR (1994) Evidence of a paracrine role of neuropeptide-Y in the regulation of insulin release from pancreatic islets of normal and dexamethasone-treated rats. Endocrinology 135: 200-206
7. Bennet WM, Wang ZL, Jones PM et al. (1996) Presence of neuropeptide-y and its messenger-ribonucleic-acid in human islets - evidence for a possible paracrine role. J Clin Endocrinol Metab 81: 2117-2120

8. Sundler F, Moghimzadeh E, Hakanson R, Ekelund M, Emson $\mathrm{P}$ (1983) Nerve fibers in the gut and pancreas of the rat displaying neuropeptide-Y immunoreactivity. Intrinsic and extrinsic origin. Cell Tissue Res 230: 487-493

9. Jamal H, Jones PM, Byrne J et al. (1991) Peptide contents of neuropeptide Y, vasoactive intestinal polypeptide, and beta-calcitonin gene-related peptide and their messenger ribonucleic acids after dexamethasone treatment in the isolated rat islets of Langerhans. Endocrinology 129: 3372-3380

10. Myrsen U, Ahren B, Sundler F (1996) Dexamethasone-induced neuropeptide $\mathrm{Y}$ expression in rat islet endocrine cells. Rapid reversibility and partial prevention by insulin. Diabetes 45: 1306-1316

11. Myrsen U, Ahren B, Sundler F (1995) Neuropeptide Y is expressed in subpopulations of insulin- and non-insulinproducing islet cells in the rat after dexamethasone treatment: a combined immunocytochemical and in situ hybridisation study. Regul Pept 60: 19-31

12. Waeber G, Thompson N, Waeber B, Brunner HR, Nicod P, Grouzmann E (1993) Neuropeptide Y expression and regulation in a differentiated rat insulin-secreting cell line. Endocrinology 133: 1061-1067

13. Larhammar D, Blomqvist AG, Yee F, Jazin E, Yoo H, Wahlestedt C (1992) Cloning and functional expression of a human neuropeptide Y/peptide YY receptor of the Y1 type. J Biol Chem 267: 10935-10938

14. Gerald C, Walker MW, Criscione L et al. (1996) A receptor subtype involved in neuropeptide-Y-induced food intake [see comments]. Nature 382: 168-171

15. Weinberg DH, Sirinathsinghji DJ, Tan CP et al. (1996) Cloning and expression of a novel neuropeptide Y receptor. J Biol Chem 271: 16435-16438

16. Rose PM, Fernandes P, Lynch JS et al. (1995) Cloning and functional expression of a cDNA encoding a human type 2 neuropeptide Y receptor. J Biol Chem 270: 22661-22664

17. Bard JA, Walker MW, Branchek TA, Weinshank RL (1995) Cloning and functional expression of a human Y4 subtype receptor for pancreatic polypeptide, neuropeptide Y, and peptide YY. J Biol Chem 270: 26762-26765

18. Dumont Y, Cadieux A, Pheng LH, Fournier A, St Pierre S, Quirion R (1994) Peptide YY derivatives as selective neuropeptide Y/peptide YY Y1 and Y2 agonists devoided of activity for the Y3 receptor sub-type. Brain Res Mol Brain Res 26: 320-324

19. Wahlestedt C, Regunathan S, Reis DJ (1992) Identification of cultured cells selectively expressing Y1-, Y2-, or Y3-type receptors for neuropeptide Y/peptide YY. Life Sci 50:PL7-PL12

20. Bottcher G, Ahren B, Lundquist I, Sundler F (1989) Peptide YY: intrapancreatic localization and effects on insulin and glucagon secretion in the mouse. Pancreas 4: 282-288

21. Lundell I, Blomqvist AG, Berglund MM et al. (1995) Cloning of a human receptor of the NPY receptor family with high affinity for pancreatic polypeptide and peptide YY. J Biol Chem 270: 29123-29128

22. Kassis S, Olasmaa M, Terenius L, Fishman PH (1987) Neuropeptide $\mathrm{Y}$ inhibits cardiac adenylate cyclase through a pertussis toxin-sensitive $G$ protein. J Biol Chem 262: 3429-3431

23. Petrenko S, Olianas MC, Onali P, Gessa GL (1987) Neuropeptide Y inhibits forskolin-stimulated adenylate cyclase activity in rat hippocampus. Eur J Pharmacol 136: 425-428 
24. Grundemar L, Wahlestedt C, Wang ZY (1993) Neuropeptide $\mathrm{Y}$ suppresses the neurogenic inflammatory response in the rabbit eye; mode of action. Regul Pept 43: 57-64

25. Skoglund G, Gross R, Ahren B, Loubatieres Mariani MM (1993) Different mechanisms are involved in neuropeptide Y-induced pancreatic vasoconstriction and inhibition of insulin secretion. Eur J Pharmacol 236: 69-74

26. Yoshimura T, Ishizuka J, Greeley GH, Thompson JC (1989) Effect of galanin on glucose-stimulated, argininestimulated, or potassium-stimulated insulin release. Am J Physiol 256:E619-E623

27. Sharp GWG (1996) Mechanisms of inhibition of insulin release. Am J Physiol Cell Physiol 40:C1781-C1799

28. Gazdar AF, Chick WL, Oie HK, Sims HL, King DL, Weir GC, Lauris V (1980) Continuous, clonal, insulin- and somatostatin-secreting cell lines established from a transplantable rat islet cell tumor. Proc Natl Acad Sci USA 77: 3519-3523

29. Hanna FW, Smith DM, Johnston CF et al. (1995) Expression of a novel receptor for the calcitonin peptide family and a salmon calcitonin-like peptide in the alpha-thyrotropin thyrotroph cell line. Endocrinology 136: 2377-2382

30. Olmos G, Kulkarni RN, Haque M, MacDermot J (1995) Imidazolines stimulate release of insulin from RIN-5AH cells independently from I1- and I2-imidazoline receptors. Ann NY Acad Sci 763: 374-376

31. Gordon EA, Kohout TA, Fishman PH (1990) Characterization of functional neuropeptide $\mathrm{Y}$ receptors in a human neuroblastoma cell line. J Neurochem 55: 506-513

32. Wahlestedt C, Regunathan S, Reis DJ (1992) Identification of cultured cells selectively expressing Y1-, Y2-, or Y3-type receptors for neuropeptide Y/peptide YY. Life Sci 50:L7-L12

33. O'Shea D, Morgan DGA, Meeran K et al. (1997) Neuropeptide $\mathrm{Y}$ induced feeding in the rat is mediated by a novel receptor. Endocrinology 138: 196-202

34. Gornall AG, Bardawill CJ, David MM (1949) Determination of serum protein by means of the biuret reaction. $\mathrm{J}$ Biol Chem 177: 751-766
35. Bhogal R, Smith DM, Owji AA, Bloom SR (1995) Binding sites for islet amyloid polypeptide in mammalian lung: species variation and effects on adenylyl cyclase. Can J Physiol Pharmacol 73: 1030-1036

36. Smith DM, Bloom SR, Sugden MC, Holness MJ (1992) Glucose transporter expression and glucose utilization in skeletal muscle and brown adipose tissue during starvation and re-feeding. Biochem J 282: 231-235

37. Bretherton Watt D, Ghatei MA, Bloom SR et al. (1989) Altered islet amyloid polypeptide (amylin) gene expression in rat models of diabetes. Diabetologia 32: 881-883

38. Eva C, Keinanen K, Monyer H, Seeburg P, Sprengel R (1990) Molecular cloning of a novel G protein-coupled receptor that may belong to the neuropeptide receptor family. FEBS Lett 271: 81-84

39. Hulme EC, Birdsall NJM (1992) Strategy and tactics in receptor-binding studies. The Practical Approach Series, vol 4. IRL Press, Oxford, pp 63-176

40. Shigeri Y, Nakajima S, Fujimoto M (1995) Neuropeptide YY1 receptors-mediated increase in intracellular $\mathrm{Ca} 2+$ concentration via phospholipase C-dependent pathway in porcine aortic smooth muscle cells. J Biochem (Tokyo) 118: 515-520

41. Nieuwenhuizen AG, Karlsson S, Fridolf T, Ahren B (1994) Mechanisms underlying the insulinostatic effect of peptide YY in mouse pancreatic islets. Diabetologia 37: 871-878

42. Persaud SJ, Jones PM, Howell SL (1990) Glucose-stimulated insulin secretion is not dependent on activation of protein kinase A. Biochem Biophys Res Commun 173: 833-839

43. Guo YS, Singh P, DeBouno JF, Thompson JC (1988) Effect of peptide YY on insulin release stimulated by 2-deoxyglucose and neuropeptides in dogs. Pancreas 3: 128-134

44. Siegel EG, Creutzfeldt W (1985) Stimulation of insulin release in isolated rat islets by GIP in physiological concentrations and its relation to islet cyclic AMP content. Diabetologia 28: 857-861 